\title{
An Institutional Framework to Explain the University-Industry Technology Transfer in a Public University of Mexico
}

\author{
Lizbeth Magdalena Puerta Sierra ${ }^{1^{*}}$, Ma. Enselmina Marín Vargas ${ }^{1}$, Virginia Guadalupe López Torres ${ }^{1}$
}

\begin{abstract}
In the last years, studies and modifications to the science and technology regulatory framework in Mexico show the increase in the attention to transfer the research results of professors and researchers from higher education institutions, towards the productive sector with the purpose of generating regional, national and international growth and development. This study has conducted to the search of the factors that determine the increase of linkage activities and technology transfer. Based on the literature review, this study develops a framework integrated with the factors considered that have a significantly impact in the university-industry linkage and technology transfer. The proposed independent variables are the following: Institutional Factors, Academic Profile, and Innovation.
\end{abstract}

Keywords: technology transfer; institutional factors; academic profile; innovation; researchers; university-industry collaboration.

Submitted: August $29^{\text {th }} 2016 /$ Approved: January $7^{\text {th }} 2017$

\section{Introduction.}

Since the industrial revolution started two centuries ago, it came with a radical change in the productive sector, and social structures, the technological and organizational innovation were the seed of these transformations. At that moment the technology was the competitive key factor, and this advantage is preserve for a strict protection; it was demonstrated not just through the exportation of the technology included in the machinery, but also through the prohibition to the engineers from England to work outside. According with this, the innovation has been considered as an important factor to the economic growth and international leadership (Heijs, 2001). And this is linked to the research activity.

According with Sabato \& Botana (1968), the research activity requires a scientific and technological structure, that integrates some articulated and interrelated elements, such as: a) the education system, that generates scientists, technicians, operators, managers; b) laboratories, institutes, centers, pilot spaces to do research; c) research committee, sciences academies; d) administrative, legal mechanisms that regulate the operation of the institutions and activities mentioned above; and e) the economic and financing resources applied to its functioning.

The triple helix denotes not only the university, industry and government relation but also the internal transformation of each of these spheres. The university has changed of a teaching institution, to in one that combines teaching with research, this is a revolution that continues, not only in the United States but also in other countries; it can play an improved role in the innovation, as well as in the increasing of knowledge-based societies. The potential of the science to promote the economic development has become a source of regional and international competence in the millennium change. The university can be seen to remain as the core institution of the knowledge sector always that keep its original education mission (Etzkowitz \& Leydesdorff, 2000).
During the last part of XIX century in the universities of United States, it was originated an embryonic entrepreneurial academic dynamic, when the absence of a research funding system, gave it more importance to the individual and collective initiatives to obtain resources to support research. The academic entrepreneurship was expanded from an organizational growing regimen towards an economic and social regional development strategy (Etzkowitz, 2003).

In Mexico, until the seventies, public universities had to focus in accomplish the substantive functions in charge. Mainly the human resources training, promote knowledge and extend and transmit its research and teaching functions. Is necessary to remember that in this period in Mexico the scientific and technological infrastructure was still developing, and the specialist's number in some areas is limited. Due to the economic crisis in Mexico in the first part of the eighties, starts the change of conception that the productive sector had about the useful of knowledge, beginning to be more valued. As a result, the industrial sector begins to request the national technological and scientific capacities, those that concentrates in public universities (De Gortari, 1997). The higher education institutions in Mexico, started formally its linkage processes in the eighties, but gains force in the nineties (Bajo, 2006).

Such as Zubieta \& Jiménez (2003) indicates, that the economic development of XXI century depends on a large degree of the successful grow of the productive sector, that at the same time, depends on the value added resulting from research and technology related to the manufacture of products and services. For that reason, is necessary the strengthening of the relationship between higher education institutions (HEI), enterprises and government. The HEI, such as knowledge entity, have to acquire new responsibilities, in the face of the explicit necessity to linkage their results of scientific research and technological development with the issues of competitiveness to industrial sector and services global scale.

(1) Universidad Autónoma de Baja California, Boulevard Zertuche y Boulevard de los Lagos S/N, Fracc. Valle Dorado, C.P. 22890, Ensenada, Baja California, México.

*Corresponding author: lizbeth_puerta@hotmail.com 
The aim of this study is to develop a framework integrated by a group of variables identified in previous studies of university-industry collaboration and technology transfer, to propose the possible dimensions and indicators for these variables; suggesting the basis of a future evaluation instrument of university-industry technology transfer to a public university of Mexico. The variables identified are the following: Institutional factors, Academic profile, and Innovation.

\section{Literature Review.}

\subsection{University-industry collaboration and technology transfer.}

Based on Debackere \& Veulegers (2005) the university-industry collaboration refers to different types of interactions between industry and science sector, which has the purpose of exchange technology. The formal forms that they consider are the following: start-up enterprises; research and development projects with firms and science institutions; contract research and know-how consultancy; intellectual property rights development; advanced training for personnel and systematic exchange of research personnel between companies and research institutes.

As reported by Shubert et al. (2014) the university-industry collaboration is used to describe the active commitment of an industry member on a research project with academics. By Lizardi \& Velázquez (2010) in its origins, the technology transfer is a linkage process that relates the driving of an idea with the delivery channel towards the intermediate or final user. The technological knowledge base mostly resides in technicians, engineers, scientists and researchers of different disciplines. It's overriding the approach between such professionals and the production and commercialization entities to achieve the technology transfer.

The technology transfer concept "relates with an active and voluntary process to disseminate or acquire new experiences or knowledge with the aim of improving products, services and productive processes of the enterprises. Commonly, this transfer is carried out with commercial agreements, for that reason the technology is treaty as merchandise" (Solleiro et al., 2012, p. 45).

On Mexico, the technology transfer is the process that involves the move of knowledge generated by the university to an enterprise, allowing innovate and extend its technological capacity, giving the possibility to obtain a competitive advantage in the market. The university technology transfer towards a firm includes 1 . Linkage activities: a) technological services, analyses, essays, calibrations, measurements, certifications, consultancy; b) training services; c) information services: national and international database search, patent search, technological information in general; d) innovation and development projects: basic and applied research, experimental development; e) enterprises incubators projects; f) junior firms projects, consultancy, and services. 2. Knowledge transfer through the intellectual property rights licensing: patents, software, plants obtained by artificial selection; as well as the not protected knowledge transfer (know-how) to consolidated enterprises in the market (Lizardi \& Velázquez, 2010).

\section{2 Technology transfer barriers.}

In America, the university-enterprise relationship has been conducted in particular circumstances deriving of the economic, technological, entrepreneurial, political and social status. Such terms determine distinctive characteristics in the university-enterprise relationship that differs from similar experiences in other countries, especially the developed world. Some problems relates with the university academics lacking culture and disposition to linkage with productive sector. Nowadays, the evaluation of professors and researchers in most of the Latin American universities basis on traditional parameters and criterion. It is for that reason that the typical Latin American university researcher prefers to dedicate its time to basic research and publish the results, given that this represents a more reliable path of rising and possibilities of salary improvement. Also, is still common to find that universities have not the suitable institutional structure to commercialize its technologies and services (Solleiro et al., 2012).

In Mexico, within the main barriers on technology transfer are the absence of an entrepreneurial culture in the Higher Education Institutions and Public Centers of Research; the limited offer of researchers and research with commercialization possibilities; the scarcity of knowledge and technology demand by firms; the lack of connection between the possible offer and demand; the reduced interaction between research, development and innovation actors; and some regulatory frames (Lizardi \& Velázquez, 2010).

The university-productive sector technology transfer has been studied by various authors in different countries, detecting factors that determine the success of this activity, as well as those that represent barriers or obstacles to achieve it. Wu et al. (2015) mention that to a large extent the researcher's attitudes and perceptions become significant; the institutional frame conditions affect the academics behavior regarding commitment in knowledge transfer activities; at the same time to

D'Este \& Patel (2007) mention that the institutional features influence the interactions established with industry. In the university-industry relation scheme proposed by Bercovitz \& Feldmann (2006), within the university environment exist formal rules that are the incentives and rewards, as well as informal rules, standard procedures of operation and norms. Finally, at the core of technology transfer is every academic motivated by a combination of personal and institutional incentives. Some personality traits and factors influence and shape the type of university-industry relationship (Shubert et al., 2014).

Additionally, the innovation is another important factor. The universities are not required only to perform an active role in education and science and technology development, also to transform their scientific results in useful innovations always that can be possible and desirable. The main competitive advantage of the universities in the knowledge market is their competence to generate new original discoveries and new approaches to solve problems (Debackere \& Veugelers, 2005).

In this sense, have been outlined three independent variables related to university-industry technology transfer (dependent variable): Institutional Factors, Academic Profile, and Innovation. For this study, the elements explains below. 


\subsection{Institutional Factors.}

Some studies emphasize in factors related to the university management (Díaz, 2014; Cabrero et al., 2011; Harman, 2010); such as the scarcity of norms and procedures (Solleiro et al., 2012; Bercovitz \& Feldmann, 2006; Bajo, 2006); research evaluation parameters, financial regulations and administrative practices to the academics involvement in activities oriented to the commercialization, as well as specific management practices of the productive sector (Solleiro et al., 2012; O'Shea et al., 2005); and the incentives (Díaz, 2014; Padilla \& Garrido, 2012; Cabrero et al., 2011; White \& Bruton, 2011; Caldera \& Debande, 2010; Link, Siegel \& Bozeman, 2007; Bercovitz \& Feldmann, 2006; O'Shea et al., 2005;).

Likewise, the focus on the execution of activities oriented to the technological and innovate objectives of the productive sector (Rubio, 2014; White \& Bruton, 2011); the limited offer of researchers and research with commercial possibilities, limited management of intellectual property rights (Cabrero et al., 2011; Lizardi \& Velázquez, 2010). The lack of information about the Technology Transfer Office (TTO) (Rubio, 2014); the insufficient experience on business and marketing of the Technology Transfer Office (Wu et al., 2015; Padilla \& Garrido, 2012; Harman, 2010; Link, Siegel \& Bozeman, 2007;); as well as its performance (D'Este et al., 2009); the lack of support in the identification of the research results that have a commercial value, as well as the discoveries documentation, and the determination of if it is possible the protection of the intellectual property rights (Rubio, 2014; Cabrero et al., 2011); are recognized as important factors in the university-industry relationship and technology transfer.

By the objective of this study and based on the literature review; the authors mentioned before, refers to different factors related to institutional issues in the university-industry technology transfer. Due to that, the Institutional Factors integrates the next elements: Technology Transfer Office (TTO); Linkage Activities Planning; Diffusion of Technological Development Projects; Incentives and Intellectual Property.

\subsection{Academic Profile.}

Some authors refers to professors and researchers as a key factor of university-industry technology transfer. The research conducted by Rivera et al. (2011) include the researcher characteristics as a variable; and is integrated by the education degree, the Researchers National System membership, funding, types of research, institution type, linkages and results. Shubert et al. (2014) proposed a group of factors to characterize the researchers profile in the information systems field, who are actively seeking the university-industry linkage; those factors are the following: organization size and type, funding source, industry members' number, university members' number, commitment, main result.

In a study carried out by D'Este \& Patel (2007) in the United Kingdom, examine the different channels through which the academic researchers interact with industry and the factors that influence the researchers' commitment on a variety of interactions. As part of this, they examine the relative impact of the institutional characteristics, as well as the individual characteristics to explain the likelihood to engage in a wide variety of interactions with the industry, and this are the number of joint publications, researcher seniority and the status.
Boardman \& Ponomariov (2009) study the individual and professional characteristics that affect the university scientist interactions with private companies, and the used ways. The authors considered a group of individual and professional predictors of the scientist's interactions with the private sector, including funding sources, institutional affiliations with research centers, peer and student collaboration, status, academic discipline and demographic attributes, such as gender, race, age and scientific values. According to Boardman \& Ponomariov (2009), gender influence the diverse types of interaction with the industry. Specifically, male scientists are more likely to be formal consultants receiving a payment; as wells as to position graduate students in industry jobs, and of being an entrepreneur (as owner or as a partner in a company), and to commercialize its research with the company personnel. On age, the old scientists are less prone to have approaches with private enterprises to request information but is more likely that they have worked with industry personnel generating patents and coauthoring papers. On the other hand, young scientists tend to socialize in an environment in which increase the closer relations between university and industry.

Giuliani et al. (2010) applied a survey to researchers of Piedmont Italy, Chile and South Africa. Their researchers focus on wine issues and diverse disciplines as viticulture, enology, agronomy, microbiology, genetics, chemistry and engineering. The authors emphasize the importance of the researcher's individual characteristics and of the institutional environment to explain the propensity towards the commitment in different types of university-industry relation. They identified some factors that influence in the likelihood of interactions between researchers and industry, within which stand out the following: researcher demographic characteristics (age and gender); researchers education characteristics (degree); and academic reputation effects (status and scientific production). They found that demographic characteristics, such as age and gender, are linked to the researcher's propensity to establish university-industry relations; while the degree background, status, and publications performance appear to have not influence in that relation. For this, the authors have two explanations: first, the education, status and publications are not perceived or have a superficial value for industry professionals; second, is possible that professionals with a higher academic degree and high scientific quality do not engage with applied research projects guided to solve practical problems relevant to the industry. Regarding to the age, younger professors tend to establish more university-industry linkage compared to older colleagues. Another interesting find is that women have a high propensity to establish relations with industry. The authors mention that a work environment that promotes the university-industry relations perhaps acts as a detonator of the women researchers capacities to engage with industry.

According to De Fuentes \& Dutrénit (2012), the main characteristics of researchers that promote long-term benefits to enterprises are related to the institutional and individual characteristics, such as field of knowledge, education degree, research equipment size and acquisition of public funding to the research. 


\subsection{Innovation.}

According to the Organisation for Economic Cooperation and Development (OECD), "the innovation is the introduction of a product (good or service) or a process, new or significantly improved, or the introduction of an organization or commercialization method, newly applied to the business practices, to the work organization or the external relations" (OCDE, 2005, p.56). For the academy context, the innovation process "is to use scientific techniques to know and define the problems that affect the cost and quality; is to apply the developed knowledges, scientific knowledge, to do something to resolve the problem, an existing problem or a necessity, innovation means that is new that does not exist before" (Casas, 2003, p. 349).

Based on Chesbrough (2003), the enterprises had a change in their conception about innovation; the author name this as closed innovation model and open innovation model. Such change consists in how business generates new ideas and bring them to market. In the closed innovation model, firms have this philosophy: successful innovation requires control. Which means, companies have to generate their ideas that subsequently will be in conditions to develop, manufacture, sell, distribute and service themselves. For years, closed innovation is understand as the right way to bring new ideas. Firms invested more in research and internal development, compared with their competitors. This enables them to reap most of the benefits, which they protected their intellectual property to prevent competitors from exploiting it. As a result, they could reinvest their profits in more research and development, which subsequently enable them progress, creating a virtuous cycle of innovation. Towards the end of the 20th century, a combination of factors started to generate a negative impact in the closed innovation model in the United States. One of these factors was the dramatic rise in the number and mobility of knowledge workers, making it difficult for companies to control their proprietary ideas and expertise.

This enables the change to the open innovation model, in which the companies commercialize external ideas (as well as internal) through the implementation of external ways (as well as in-house) to market. The ideas can originate outside of the firm's labs and be brought inside to its commercialization; with this the University gained significant contribution and played an important role in the open innovation model.

In the open innovation context, the universities have a crucial role since they are institutions that cooperate and share knowledge with other organizations in knowledge transfer exchange processes. The researchers as part of universities, are involved in the technology transfers interchange processes, and for that reason, are ultimate elements. Consequently, is important to understand which factors influence the researcher's commitment in the open innovation context (Padilla \& Garrido, 2012).

\section{Research Aim.}

The purpose of this study is to develop a framework integrated by a group of variables identified in previous studies of university-industry collaboration and technology transfer. The independent variables identified are the following: Institutional Factors, Academic Profile, and Innovation.

The specific objectives of this study are the following:

Objective 1. Identify in the literature review the factors involved in the independent's variables.

Objective 2. Develop a framework for university-industry technology transfer in a public university of Mexico.

\section{Research Methodology.}

This study basis on significant findings obtained in previous studies of university-industry collaboration and technology transfer. For that reason, and with the purpose of identifying the independent variables with their dimensions and indicators, has been developed a framework that could explain the university-industry collaboration and technology transfer in a context of a public university of Mexico.

\section{University-Industry Technology Transfer Conceptual Framework.}

This section presents the university-industry technology transfer framework and the dimensions and indicators of the independent variables (Institutional Factors, Researcher Profile, and Innovation). The authors of this study consider that the Institutional factors, Academic Profile, and Innovation determine the University-Industry Technology Transfer. Is outstanding to mention that based on the literature review, this paper refers to university collaboration/linkage and technology transfer to another different context, as university-industry or university/productive sector collaboration/relation/technology transfer.

Figure 1. A Framework for University-Industry Collaboration and Technology Transfer.

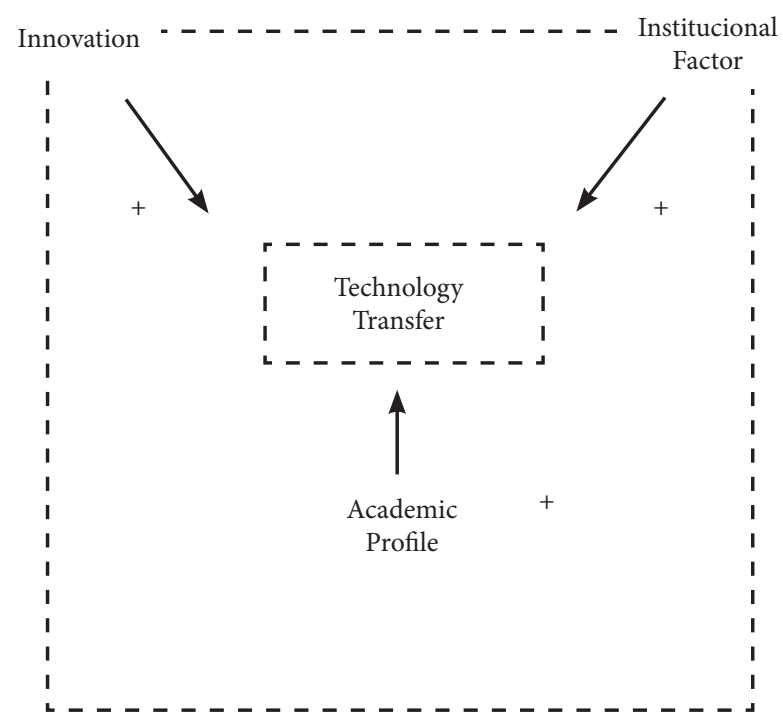

Source: Own elaboration. 
Table 1. Dimensions and indicators proposed to the Institutional Factors independent variable.

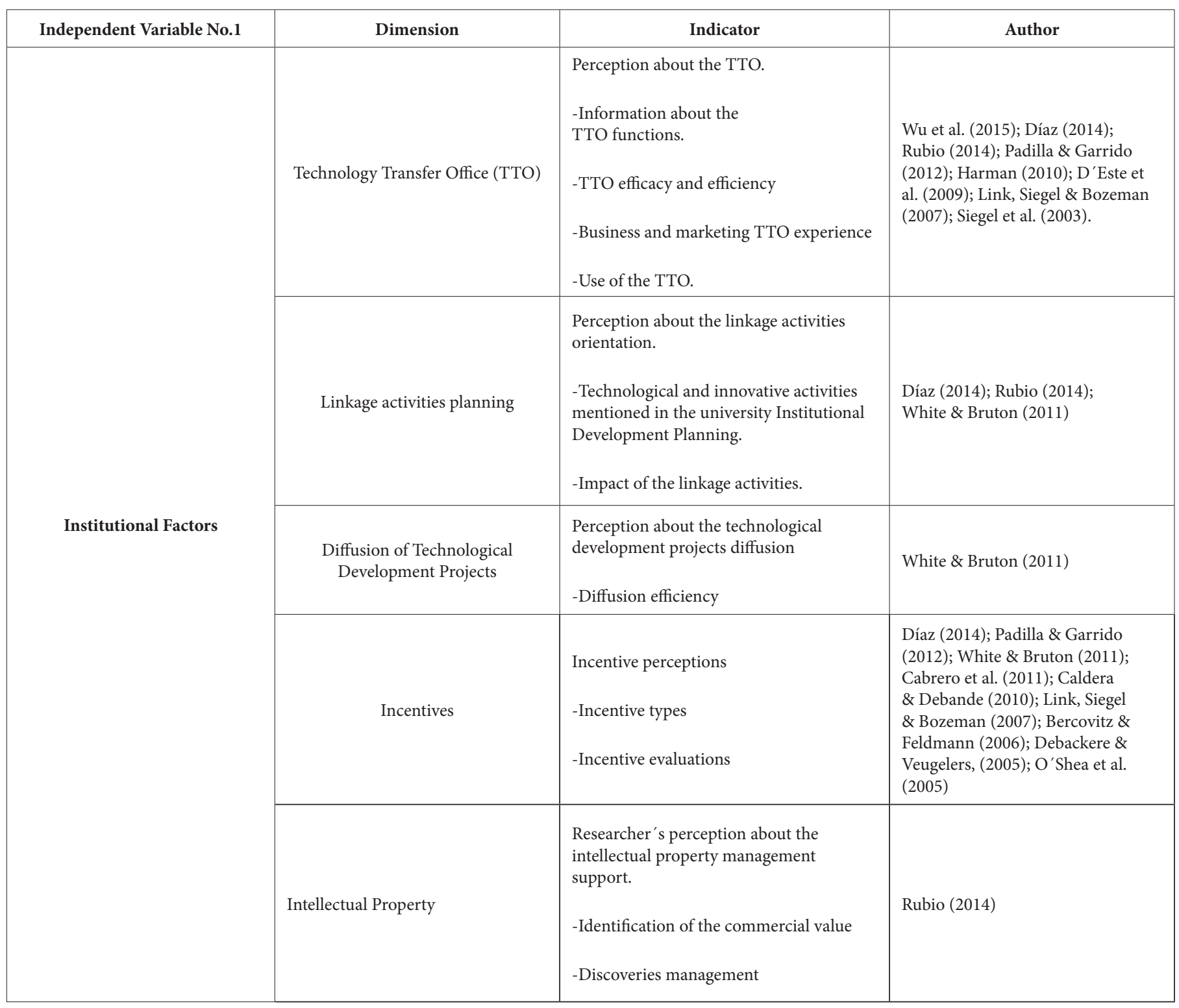

Source: Own elaboration.

As is mentioned by Lizardi \& Velázquez (2010) the technological knowledge resides in the human capital involve in a science and academic context; for that reason in technological change and innovation, is relevant to know how professors and researchers perceive the Institutional Factors. It infers that a positive perception of the management of this factors, could influence positively in the linkage and technology transfers activities of the professors and scientists.

Some authors emphasize in the TTO role in the university, the indicator of perception of TTO suggest determining if the professor or researcher is informed about the TTO functions and how is perceived its performance. The dimension of linkage activities planning, attempt to know how the academics notice the university efforts are in linkage activities planning; the same occurs with the Diffusion of Technological Development Projects. A factor mentioned by different authors is the incentives, for that reason is interesting to know the type of incentives (additional payment per project, scholarships, among others) that professors and researchers are obtaining with this activities and how do they perceive the evaluation to gain access to them. The research results of some researchers suggest the intellectual property management support; therefore, is considered significant to explore what is the professors and researchers perception about the university support in this field (Table 1). 
Table 2. Dimensions and indicators proposed to the Academic Profile independent variable.

\begin{tabular}{|c|c|c|c|}
\hline Independent variable No.2 & Dimension & Indicator & Author \\
\hline \multirow[b]{3}{*}{ Academic profile } & Individual characteristics & $\begin{array}{l}\text {-Age } \\
\text {-Gender } \\
\text {-Degree }\end{array}$ & $\begin{array}{l}\text { Callaert et al. (2015); Rivera et } \\
\text { al. (2011); Giuliani et al. (2010); } \\
\text { Boardman \& Ponomariov, (2009); } \\
\text { D'Este \& Patel, (2007) }\end{array}$ \\
\hline & Professional characteristics & $\begin{array}{l}\text {-Seniority } \\
\text {-Status } \\
\text {-Faculty }\end{array}$ & $\begin{array}{l}\text { Shubert et al. (2014); } \\
\text { Boardman \& Ponomariov, (2009); } \\
\text { D'Este \& Patel, (2007) }\end{array}$ \\
\hline & Research Project & $\begin{array}{l}\text {-Project area } \\
\text {-Project registration category } \\
\text {-Economic sector } \\
\text {-Organization type } \\
\text {-Organization size } \\
\text {-Project scope } \\
\text {-Project management channel }\end{array}$ & $\begin{array}{l}\text { Callaert et al. (2015); Shubert et } \\
\text { al. (2014); Rivera et al. (2011); } \\
\text { Boardman y Ponomariov, (2009); } \\
\text { Luna \& Velasco (2003); Meagher } \\
\text { (2003); Casas (2003). }\end{array}$ \\
\hline
\end{tabular}

Source: Own elaboration.

In respect of the researcher profile, is interesting to determine if in the context of a Mexican public university, characteristics such as age, gender and degree influence their activities of linkage and technology transfer. Also, the type of projects in which they tend to engage with other institutions. The project area refers the field of knowledge in which the professor/researcher is involved. Additionally, the project registration category allows knowing if the project guided by a researcher or a group of researchers. With the economic sector can be identified if the user is from the primary, secondary or tertiary sector; the same occurs with the organization type, due to can be a public entity, a private entity (national or foreign) or Higher Education Institution. Other important indicators are the project scope (local, regional, national or international) and project management channel, that the University offers, requested by the user or that the researcher searched for the user (Table 2).

Table 3. Dimensions and indicators proposed to the Innovation independent variable.

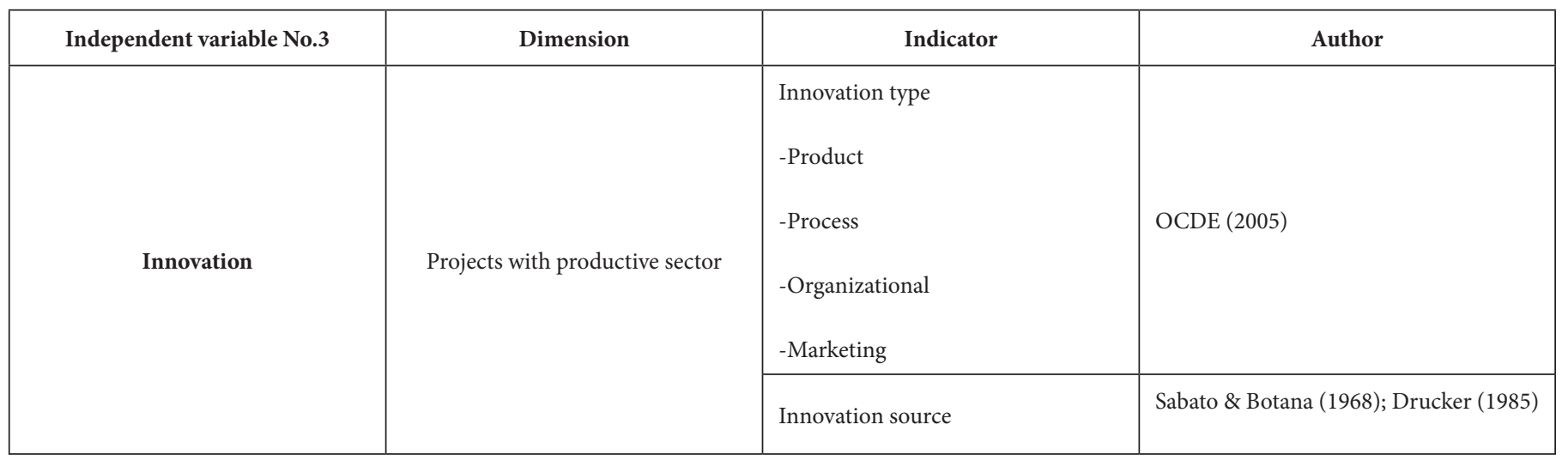

Source: Own elaboration. 
The innovation variable suggest to explore the type of innovation projects in which the professors and researchers have participated, also the source of this innovation, such as search of customer's needs, internal processes needs, market changes needs and regional development needs (Table 3).

Table 4. Dimensions and indicators proposed to the Technology transfer dependent variable.

\begin{tabular}{|l|l|l|l|}
\hline Dependent variable & \multicolumn{1}{|c|}{ Dimension } & \multicolumn{1}{c|}{ Indicator } & \multicolumn{1}{c|}{ Author } \\
\hline \multirow{2}{*}{ Technology transfer } & Professor and researcher perceptions (2014); Rubio (2014); & $\begin{array}{l}\text { Debackere \& Veugelers (2005); Luna } \\
\text { \& Velasco (2003); Meagher (2003); } \\
\text { Casas (2003); Siegel et al. (2003) }\end{array}$ \\
\cline { 2 - 4 } & Research project result & -Barriers & Rivera et al. (2011) \\
\cline { 2 - 4 } & $\begin{array}{l}\text { Linkage and technology transfer } \\
\text { background }\end{array}$ & -Activity type & $\begin{array}{l}\text { Lizardi \& Velázquez (2010); D'Este \& } \\
\text { Patel (2007) }\end{array}$ \\
\hline
\end{tabular}

Source: Own elaboration.

In relation to the technology transfer variable, is important to explore the professor and researcher perceptions, as the barriers (link between project members; funding resources scarcity, excess of procedures; time; technical aspects; geographic distance and academic and industry personnel differences of training) and benefits (to obtain ideas for new projects; to accomplish ideas for more research; information/knowledge exchange; reputation; equipment and instruments exchange; publications; additional payment; funding for graduate and postdoctoral students) that can promote or hinder their propensity to engage in collaboration research projects. Also is important to identify the activity type in which tend to involve, to characterize according to the field of knowledge; and the type of result obtained with the research as an intellectual property registration (Table 4).

\section{Conclusions}

In recent years the knowledge and scientific research has been seen strategically for government and higher education institutions. In the university context, has increased the interest and necessity to generate research projects with significant potential to be transferred to different users, such as industry, government, and society in general. Therefore, the university conceived as an entity with human capital in the knowledge frontier, have to explore the factors that determine the university-industry collaboration and technology transfer to improve the institutional environment and to achieve the research results transfer.

The framework proposed, can be used as a basis to develop a measurement instrument in a future study; and explain the relation between the Institutional Factors, Researcher Profile, Innovation and the Technology Transfer in the context of a public university in Mexico. In this study the researcher's perceptions, experiences, and characteristics play an important role understanding their position in the innovation and technological change.

\section{References}

Bajo, A. (2006). La vinculación de las IES y los sectores productivos en el noroeste de México: modalidades de gestión y transferencia. En López, S., Barrón, D. y Corona, L. (Coord), Políticas para la innovación en México, Memoria del VII Seminario de Territorio, Industria y Tecnología (pp. 107-134). México: Universidad Autónoma de Sinaloa Editorial.

Bercovitz, J., \& Feldmann, M. (2006). Entpreprenerial Universities and Technology Transfer: A Conceptual Framework for Understanding Knowledge-Based Economic Development. Journal of Technology Transfer, 31, 175-188. DOI: 10.1007/s10961-005-5029-z

Boardman, C. \& Ponomariov, B. (2009). University researchers working with private companies. Technovation, 29, 142-153. http://dx.doi.org/10.1016/j.technovation.2008.03.008

Cabrero, E., Cárdenas, S., Arellano, D., y Ramírez, E. (2011). La vinculación entre la universidad y la industria en México. Una revisión a los hallazgos de la Encuesta Nacional de Vinculación. Perfiles Educativos, 33, 186-199. http://www.scielo.org.mx/pdf/ peredu/v33nspe/v33nspea16.pdf

Caldera, A. \& Debande, O. (2010). Performance of spanish universities in technology transfer: an empirical analysis. Research policy, 39, 1160-1173. http://dx.doi.org/10.1016/j.respol.2010.05.016

Callaert, J., Landoni, P., Looy, B. \& Verganti, R. (2015). Scientific yield from collaboration with industry: The relevance of researchers' strategic approaches. Research Policy, 44, 990-998. http://dx.doi. org/10.1016/j.respol.2015.02.003

Casas, R. (2003). Intercambio y flujos de conocimiento en las redes. En Luna, M. (Coord), Itinerarios del conocimiento: formas dinámicas y contenido, (pp. 306-354). México: Anthropos Editorial. 
Chesbrough, H. (2003). The Era of Open Innovation. MIT Sloan Management Review.

Debackere, K. \& Veugelers, R. (2005). The role of academic technology transfer organizations in improving industry science links. Research Policy 34, pp. 321-342. http://dx.doi.org/10.1016/j.respol.2004.12.003

D'Este \& Patel, P. (2007). University-industry linkages in the UK: What are the factors underlying the variety of interactions with industry?. Research Policy 36, 1295-1313. http://dx.doi.org/10.1016/j. respol.2007.05.002

De Fuentes, C. \& Dutrénit, G. (2012). Best channels of academiaindustry interaction for long-term benefit. Research Policy, 41, 16661682. http://dx.doi.org/10.1016/j.respol.2012.03.026

De Gortari, R. (1997). Los académicos: de la producción a la comercialización del conocimiento. En Casas, R. y Luna, M. (Coord), Gobierno, academia y empresas en México, hacia una nueva configuración de las relaciones (pp. 137-160). México: Plaza y Valdés Editores.

Díaz, C. (2014). Patentes académicas de México. México: ANUIES, Dirección de Producción Editorial.

Drucker, P. (1985). The Discipline of innovation. Harvard Business Review.

Etzkowitz, H. (2003). Research groups as 'quasi-firms': the invention of the entrepreneurial university. Research Policy 32, pp. 109-121. http://dx.doi.org/10.1016/s0048-7333(02)00009-4_

Giuliani, E., Morrison, A., Pietrobelli, C. \& Rabellotti, R. (2010). Who are the researchers that are collaborating with industry? An analysis of the wine sectors in Chile, South Africa and Italy. Research Policy, 39, 748-761. http://dx.doi.org/10.1016/j.respol.2010.03.007

Harman, G. (2010). Australian university research commercialisation: perceptions of technology transfer specialists and science and technology academics. Journal of Higher Education Policy and Management, 32 (1), 69-83. http://dx.doi. org/10.1080/13600800903440568

Heijs, J. (2001). Sistemas nacionales y regionales de innovación y política tecnológica: una aproximación teórica. Instituto de Análisis Industrial y Financiero. Documento de trabajo no.24.

Hetzkowitz, H. \& Leydesdorff, L. (2000). The dynamics of innovation: from National Systems and "Mode 2" to a Triple Helix of universityindustry-government relations. Research Policy 29, pp. 109-123. http://dx.doi.org/10.1016/s0048-7333(99)00055-4

Link, A., Siegel, D. \& Bozman, B. (2007). An empirical analisys of the propensity of academics to engage in informal university technology transfer. Industrial and Corporate Change, 16 (4), 641-655. http://dx.doi.org/10.2139/ssrn.902207
Lizardi, V. \& Vázquez, L. (2010). Oficinas de Transferencia de Tecnología. Fundamentos para su formación y operación en México. ADIAT.

Luna, M. \& Velasco, J. (2003). El vínculo entre las empresas y las instituciones académicas: la función de traducción y el perfil de los traductores. En Luna, M. (Coord), Itinerarios del conocimiento: formas dinámicas y contenido, (pp. 229-258). México: Anthropos Editorial.

Meagher, M. (2003). Orientaciones normativas: Percepciones del sector académico y el empresarial acerca de sus relaciones en red. En Luna, M. (Coord), Itinerarios del conocimiento: formas dinámicas y contenido, (pp. 259-305). México: Anthropos Editorial.

OCDE (2005). Manual de Oslo. Guía para la recogida e interpretación de datos sobre innovación. (3ra Edición).

O'Shea, R., Allen, T., Chevalier, A. \& Roche, F. (2005). Entrepreneurial orientation, technology transfer and spinoff performance of U.S. universities. Research Policy 34, pp. 994-1009. http://dx.doi.org/10.1016/j.respol.2005.05.011

Padilla, A., \& Garrido, A. (2012). Open innovation in universities. What motivates researchers to engage in knowledge transfer exchanges?. International Journal of Entrepreneurial Behaviour \& Research, 18 (4), 417-439. http://dx.doi.org/10.1108/13552551211239474

Rivera, R., Dutrénit, G., Ekboir, J., Sampedro, J. \& Vera-Cruz, A. (2011). Do linkages between farmers and academic researchers influence researcher productivity? The Mexican case. Research Policy, 40, 932-942. http://dx.doi.org/10.1016/j.respol.2011.05.001_

Rubio, T. (2014). Recomendaciones para mejorar el modelo de transferencia de tecnología en las universidades españolas. Conferencia de Consejos Sociales de las Universidades Españolas.

Sabato, J. \& Botana, N. (1968). La ciencia y la tecnología en el desarrollo futuro de América Latina. En Sabato, J. (Coord), El pensamiento latinoamericano en la problemática cienciatecnología-desarrollo-dependencia (pp. 215-234). Argentina: Ediciones Biblioteca Nacional.

Shubert, P., Killian, T., \& Bjorn, N. (2014). "I am an engaged scholar": a typology of IS researchers' engagement in research with industry. Procedia Technology 16 (pp. 138-149). http://dx.doi.org/10.1016/j. protcy.2014.10.077

Siegel, D., Waldman, D., \& Link, A. (2003). Assessing the impact of organizational practices on the relative productivity of university technology transfer offices: An Exploratory Study. Research Policy, 32, 27-48. http://dx.doi.org/10.1016/s0048-7333(01)00196-2_

Solleiro, J., Ritter, E. \& Castañón, R. (2012). Prácticas para la vinculación exitosa de universidades con el sector productivo. En Medellín, E. (Coord), Vinculación para la innovación, reflexiones y experiencias (pp. 19-50). México: Fundación Educación SuperiorEmpresa, ANUIES. 
White, M., \& Bruton, G. (2011). The Management of Technology and Innovation: A Strategic Approach. OH, USA: South-Western Cengage Learning.

Wu, Y., Welch, E. \& Huang, W. (2015) Commercialization of university inventions: Individual and institutional factors affecting licensing of university patents. Technovation 36-37, 12-25. http://dx.doi. org/10.1016/j.technovation.2014.09.004
Zubieta, J. \& Jiménez, J. (2003). Acercamientos entre academia e industria: el futuro de la vinculación. En Santos, M. (Coord), Perspectivas y desafíos de la educación, la ciencia y la tecnología (pp. 271-334). México: Universidad Autónoma de México, Instituto de Investigaciones Sociales. 